\title{
Barriers to Integrated Flood Risk Management Adaptation in a Developing Country
}

\author{
Akira Kawamura* and Jean Margaret R Mercado \\ Department of Civil and Environmental Engineering, Tokyo Metropolitan University, Japan
}

Submission: December 06, 2019; Published: December 13, 2019

*Corresponding author: Akira Kawamura, Department of Civil and Environmental Engineering, Tokyo Metropolitan University, 1-1 Minami-Osawa, Hachioji, Tokyo, Japan

\begin{abstract}
Research on the barriers to IFRM adaptation in developing countries remains limited to almost no study. Hence, this study identifies key barriers to IFRM adaptation in a megacity of a developing country, Metro Manila, Philippines, by conducting a comprehensive review of the literature. From the literature review, there are 12 barriers in Metro Manila which we categorized into the governance, social, and technological resources aspects. Some barriers in the governance aspect are similar to those found in developed countries, but some barriers in the social and technological resources aspect are regarded as unique because these barriers are contextual to prevailing socio-economic conditions of a developing country. Collectively, the barriers to IFRM adaptation in a developing country are more numerous, complex, and some are unique than those found in developed countries.
\end{abstract}

Keywords: Barriers; Developing country; Integrated flood risk management

\section{Background}

Policy changes in flood risk management were catalyzed by the dramatic increase of urban flood disasters across the globe in the last decades, and this led to a shift towards the integrated flood risk management (IFRM) in managing urban flood. The IFRM is a relatively modern approach that goes beyond flood protection and includes measures for prevention and preparedness [1]. More specifically, IFRM combines structural and non-structural measures, in which non-structural measures are becoming more critical than structural measures.

The IFRM is being implemented in some developed countries in Europe. However, these European countries experienced "barriers" or issues that hindered or delayed the transition to IFRM from the traditional reliance on hard engineering measures [2-4]. Meanwhile, developing countries are still transitioning to IFRM, while some countries have not yet considered implementing this approach. The barriers that could hamper the smooth adaptation of IFRM in developing countries are expected to be more severe and alarming than those in the developed countries, because general condition between developed and developing countries profoundly differ from each other. However, the barriers to IFRM adaptation in developing countries have not yet been identified. Based on the experiences of the developed countries, it is a crucial task to identify the barriers to IFRM adaptation in developing countries so that decision-makers and practitioners can devise a plan or propose policy changes in order to overcome the barriers.

Hence, this study identifies for the first time the barriers to IFRM adaptation in a megacity of a developing country, particularly Metro Manila, Philippines. We focused our study on Metro Manila, the capital region of the Philippines because it is considered to be the most at risk to climate impacts among the megacities in Asia due to its exposure to tropical cyclones. The identification of barriers to IFRM needs to be case-specific so that various facets of problems in flood control and management can be included. For this study, we examined 22 published journal articles and project reports in the last two decades that discuss issues in flood management to draw out the barriers to IFRM adaptation in Metro Manila. The barriers to IFRM adaptation in Metro Manila were noted if they are recurring issues concerning flood management or cited at least once in the literature.

\section{Results and Discussion}

From the comprehensive review of literature, we have identified 12 barriers to IFRM adaptation in Metro Manila as shown in Table 1. The identified barriers are relatively numerous than those reported in developed countries, because countries like the Netherlands, Italy, and Romania have encountered a 
total of four barriers during their transition to IFRM. Thus, we categorized the identified barriers in Metro Manila into three aspects, governance, social, and technological aspects, in which each aspect have four, three, and five barriers, respectively. The barriers in the governance aspect are lack of a sole organizing body, lack of communication, lack of funding, and lack of flood control measures. These barriers describe the challenges in maintaining flood management capabilities in Metro Manila because of overlapping and gaps in responsibilities between institutions and poor communication among them that resulted in the faulty implementation of flood-related projects. The barriers in this aspect are similar to those found in developed countries. For instance, the lack of a sole organizing body is similar to barrier experienced in Italy which is the fragmented governance structure for flood management [2]

Table 1: Identified barriers to IFRM adaptation in Metro Manila, Philippines.

\begin{tabular}{|c|c|c|}
\hline Aspect & Code & Barrier \\
\hline \multirow{4}{*}{ Governance } & G1 & Lack of a sole organizing body \\
\hline & G2 & Lack of communication \\
\hline & G3 & Lack of funding \\
\hline & G4 & Lack of flood control measures \\
\hline \multirow{3}{*}{ Social } & S1 & Informal settlers \\
\hline & S2 & Poor solid waste management \\
\hline & S3 & Poor social planning \\
\hline \multirow{5}{*}{ Technological Resources } & T1 & Lack of technological capabilities \\
\hline & $\mathrm{T} 2$ & Sparse data and limited access \\
\hline & T3 & Lack of experts \\
\hline & $\mathrm{T} 4$ & Lack of data processing systems \\
\hline & T5 & Deterioration of flood control structures \\
\hline
\end{tabular}

The barriers in the social aspect are informal settlers, poor solid waste management, and poor social planning. These barriers are related to urban growth and society's standard of living in a developing country. Among the barriers in the social aspect, the informal settlers and poor solid waste management can be considered as unique barriers because these are uncommon phenomenon in developed countries. Moreover, these two social aspect barriers are dependent on normative behaviors and socio-economic conditions in a developing country. The poor social planning, on the other hand, can be closely associated with the barrier found in developed countries regarding the weak enforcement of building restriction. Meanwhile, the barriers in the technological resources aspect are lack of technological capabilities, sparse data and limited access, lack of experts, lack of data processing systems, and deterioration of flood control structures. These barriers are related to the systems that support decision-making based on scientific evidence and are associated with the current technologies used to alleviate flooding in Metro Manila. The barriers in the technological aspect can also be regarded as unique barriers because, unlike in developed countries, the Philippines struggles to keep up with global technological advancement. These barriers resulted from the lack of prioritization and funding, because funding is usually allocated firstly to immediate concerns and revenue-generating projects in the country. Thus, the Philippines have relied on international aid in the past regarding upgrade and the acquisition of the necessary technologies related to flood management. Overall, the identified barriers to IFRM adaptation can be regarded as more numerous, complex, while some are unique than those found in developed countries.

\section{References}

1. Buchecker M, Ogasa DM, Maidl E (2016) How well do the wider public accept integrated flood risk management? An empirical study in two Swiss Alpine valleys. Environ Sci Policy 55: 309-317.

2. Mysiak J, Testella F, Bonaiuto M, Carrus G, De Dominicis S, et al. (2013) Flood risk management in Italy: Challenges and opportunities for the implementation of the EU Floods Directive (2007/60/EC). Nat Hazards Earth Syst Sci13(11): 2883-2890.

3. Samuels P, Klijn F, Dijkman J (2005) An analysis of the current practice of policies on river flood risk management in different countries. Irrig Drain 55(S1): S141-S150.

4. van Herk S, Rijke J, Zevenbergen C, Ashley R (2015) Understanding the transition to integrated flood risk management in the Netherlands. Environmental Innovation and Societal Transitions 15: 84-100. 
Your next submission with Juniper Publishers will reach you the below assets

- Quality Editorial service

- Swift Peer Review

- Reprints availability

- E-prints Service

- Manuscript Podcast for convenient understanding

- Global attainment for your research

- Manuscript accessibility in different formats ( Pdf, E-pub, Full Text, Audio)

- Unceasing customer service

Track the below URL for one-step submission https://juniperpublishers.com/online-submission.php 